\title{
Willingness to Communicate in English among Iranian EFL Students
}

\author{
Mohammad Aliakbari ${ }^{1}$, Mohsen Kamangar ${ }^{1}$ \& Reza Khany ${ }^{1}$ \\ ${ }^{1}$ English Department, Ilam University, Ilam, Islamic Republic of Iran \\ Correspondence: Mohsen Kamangar, Sanandaj, Kurdistan, Islamic Republic of Iran. Postal Code: 66187-56511, \\ Iran. Tel: 98-918-381-8128. E-mail: m.kamangar@hotmail.com
}

Received: February 13, 2016 Accepted: April 2, 2016 Online Published: April 5, 2016

doi: 10.5539/elt.v9n5p33

URL: http://dx.doi.org/10.5539/elt.v9n5p33

\begin{abstract}
Much has been written on the determinants that can expedite or hinder learners' willingness to communicate in second and foreign language contexts. Though the literature is abundant with studies on many of these variables, little if any can be found to have targeted EFL students of private institutes in Iran. An effort was made in this study to examine the simultaneous impact of anxiety, self-confidence, communicative competence, and international posture on 194 Iranian EFL students' willingness to communicate. To this end, a structural equation modeling analysis was used to examine the proposed model of the study. The results revealed that students' willingness to communicate is directly related to their attitude toward the international community, their perceived linguistic competence and self-confidence. The study concludes with certain pedagogical implications.
\end{abstract}

Keywords: willingness to communicate, anxiety, communicative competence, international posture, EFL students

\section{Introduction}

Since the goal of second language (L2) and foreign language (FL) learning is to facilitate better communication and understanding between individuals who come from different cultural backgrounds and different languages, MacIntyre, Clément, Dörnyei, and Noels (1998) emphasized communicative goals using the conceptual model of willingness to communicate (WTC). In this regard L2 proficiency is not considered as the ultimate goal of L2 learning but is seen as a means to achieve interpersonal/intercultural goals. Both state and trait variables, including self-confidence, intergroup motivation, intergroup attitudes, and personality, were shown to affect one's WTC in the L2 in a given situation. Contextual variables, such as when and where and to whom one is communicating, also affects ones desire to initiate and maintain communication.

Willingness to communicate is defined as a learner's "readiness to enter into discourse at a particular time with a specific person or persons, using a L2" (MacIntyre et al., 1998, p. 547). As Dörnyei (2003) points out, competence in the L2 may not be enough. Learners need to be not only able to communicate but also willing to communicate in the L2. Research has shown that a learner's WTC influences how frequently the learner actively engages in communicating in the L2 (Clément et al., 2003; Yashima et al., 2004). Thus MacIntyre et al. (1998) propose that WTC in L2 should be conceptualized as the primary goal of language instruction and as a comprehensive conceptual framework to describe, explain and predict L2 communication behavior.

Regarding previously done studies various linguistic, communicative, and social variables affect WTC. "These variables include state of communicative self-confidence, desire to communicate with a specific person; self-confidence, intergroup and interpersonal motivation; communicative competence, social attitudes, and intergroup attitudes; and personality and intergroup climate." (Ghonsooly et al., 2012, p. 198)

Language and communication are cultural matters. McCroskey and Richmond (1990) suggested that the relationship between WTC and other variables might be different from one culture to another. Studies of WTC have been conducted in Australia (Barraclough, Christophel, \& McCroskey, 1988), Sweden, (McCroskey, Burroughs, Daun, \& Richmond, 1990), Micronesia (Burroughs \& Marie, 1990; Burroughs, Marie, \& McCroskey, 2003), Finland (Sallinen-Kuparinen, McCroskey, \& Richmond, 1991), Korea (Kim, 2004), and Japan (Matsuoka, 2005; Yashima, 2002), China (Wen \& Clément, 2003; Hsu, 2005), but few have been done in Iran (Ghonsooly et al., 2012; Zarrinabadi \& Abdi, 2011; Barjesteh et al., 2012). Most of this studies have been conducted in settings where English is learned as a second language while according to Oxford and Shearin (1994) the differences between second language and foreign language settings could highly affect language learners. Those studies 
which have been done in Iran were aiming at investigating some variables which are not of interest in this study. The current study investigates L2 WTC among Iranian English learners who study English as a foreign language in private institutes.

Accordingly, the present study is an attempt to investigate the relationships among the variables which are believed to affect WTC in English among Iranian EFL students. These factors include language anxiety, self-confidence, perceived communicative competence, and international posture.

The objectives of the study are: 1) Examine the relationships among Anxiety, self-confidence, International posture, Communicative competence, and WTC. 2) Create a model using the mentioned variables.

The research questions of the study are:

1) What are the relationships among anxiety, self-confidence, international posture, communicative competence, and L2WTC?

2) To what extend each of mentioned variables affect L2WTC?

\section{Review of the Literature}

\subsection{Language Anxiety}

Learning has two main domains: Affective and Cognitive (Brown, 1994). Anxiety as an affective feature of learning is defined by MacIntyre (1998) as a feeling of worry and emotional reaction that arises while learning. Rachman, (1998) defines anxiety as the tense, unsettling anticipation of a threatening but vague event, a feeling of uneasy suspense. Spielberger (1983, p. 15) defines anxiety as "subjective feeling of tension, apprehension, nervousness and worry associated with the arousal of the nervous system". Generally we can say that anxiety is an uneasy feeling caused by something threatening. It is a type of performance problem like when some people get nervous trying new things. According to a variety of researchers (e.g., Horwitz, Horwitz, \& Cope, 1986; MacIntyre \& Gardner, 1989, 1991a, 1991b), foreign language anxiety can be a predictor of success in learning the foreign language. It can be said that those students with relaxed personal conditions are benefiting from the second language class more than the anxious students. During this period of anxiety students go through feelings of worry and dread, have trouble concentrating, sweat, experience heart palpitations, and become forgetful. These psycho-physiological symptoms hinder the language learning experience (Horwitz et al., 1986).

Horwitz (1986) developed The Foreign Language Classroom Anxiety Scale to assess three components of anxiety: communication apprehension, test anxiety, and fear of negative evaluation. The relationship between communication apprehension, which is directly related to oral communication anxiety, and WTC has been investigated in many studies and all of them have shown that there is a negative relationship between L2WTC and anxiety (Gardner \& MacIntyre, 1993; Hashimoto, 2002; MacIntyre \& Clément, 1996; Yashima, 2002; Ghonsooly et al., 2012). So, those are less anxious are more willing to communicate in L2.

\subsection{Confidence in L2 Communication}

One of the personal factors, which is highly correlated with anxiety, is self-confidence. Self-confidence involves judgments and evaluations about one's own value and worth. It can also be positively correlated with oral performance (Heyde, 1979). Two kinds of self-confidence, state and trait-like self-confidence have been defined by McIntyre (1998). State self-confidence, which is the interest of this study, is a momentary feeling of confidence, which may be transient within a given situation. Studies continuously indicated negative relationship between learners' self-perception of their communicative competence and anxiety (Cheng, Horwitz, \& Schallert, 1999; MacIntyre, Noels, \& Clément, 1997; Noels, Pon, \& Clément, 1996; Clément, Dörnyei, \& Noels, 1994; Clément, Gardner, \& Smythe, 1980). Clément (1980) maintains that one's self-confidence in his language ability and his anxiety level can better predict his language achievement and consequently his language use. Revealed by Clément's study (1986) with Francophone students in Canada, self-confidence is positively associated with the oral language production of students. He also indicated that students' self-confidence is related to integrativeness and inter-ethnic contact.

\subsection{Perceived Communicative Competence}

Communicative competence refers to language user's grammatical knowledge of syntax, morphology, phonology and the like, as well as social knowledge about how and when to use utterances appropriately. A survey of communicative competence by Bachman (1990) divides it into the broad headings of "organizational competence," which includes both grammatical and discourse (or textual) competence, and "pragmatic competence," which includes both sociolinguistic and "illocutionary" competence. Research in WTC have shown the importance of a person's perception of her/his communication competence (McCroskey \& McCroskey, 
1986; McCroskey \& Richmond, 1985), so those who perceive themselves as competent are more willing to engage in communication. In this regard, communicative competence is believed to greatly affect WTC. Several researchers (Hashimoto, 2002; Matsuoka, 2005; Yashima, 2002) investigated the relation between perceived communicative competence, WTC, and anxiety in university students. Results revealed the positive relationship between perceived communicative competence and WTC and negative relationship between perceived communicative competence and anxiety. Ghonsooly et al. (2012), following Clément $(1980,1986)$, considered L2 self-confidence as anxiety and perceived communicative competence. His study showed that as anxiety decreases perceived communicative competence increases, and WTC increases too.

\subsection{Willingness to Communicate}

Willingness to communicate can be defined as the probability of engaging in communication (McCroskey \& Baer, 1985). It is the desire to speak in the second or foreign language. The concept of WTC was first introduced with reference to first or native language. It was brought into communication literature by McCroskey and Richmond (1987). McCroskey and his associates suggested that WTC reflected a stable predisposition to talk, which was relatively consistent across a variety of communication contexts and types of receivers. According to MacIntyre et al. (1998) "it is highly unlikely that WTC in the second language is a simple manifestation of WTC in the L1" (p. 546). Accordingly, WTC in second language (L2WTC) was defined as a readiness to enter into discourse at a particular time with a specific person or persons, using a second language. MacIntyre et al. (1998) proposed a heuristic model of the WTC construct with an account of linguistic, communicative, and social psychological variables that might affect one's WTC in a second language communication context. The model proposes various potential influences on willingness to communicate in a second language. As it can be seen in Figure 1, three layers of influences represent situation- specific influences and three layers represent stable, enduring influences on second language communication (MacIntyre et al., 1998).

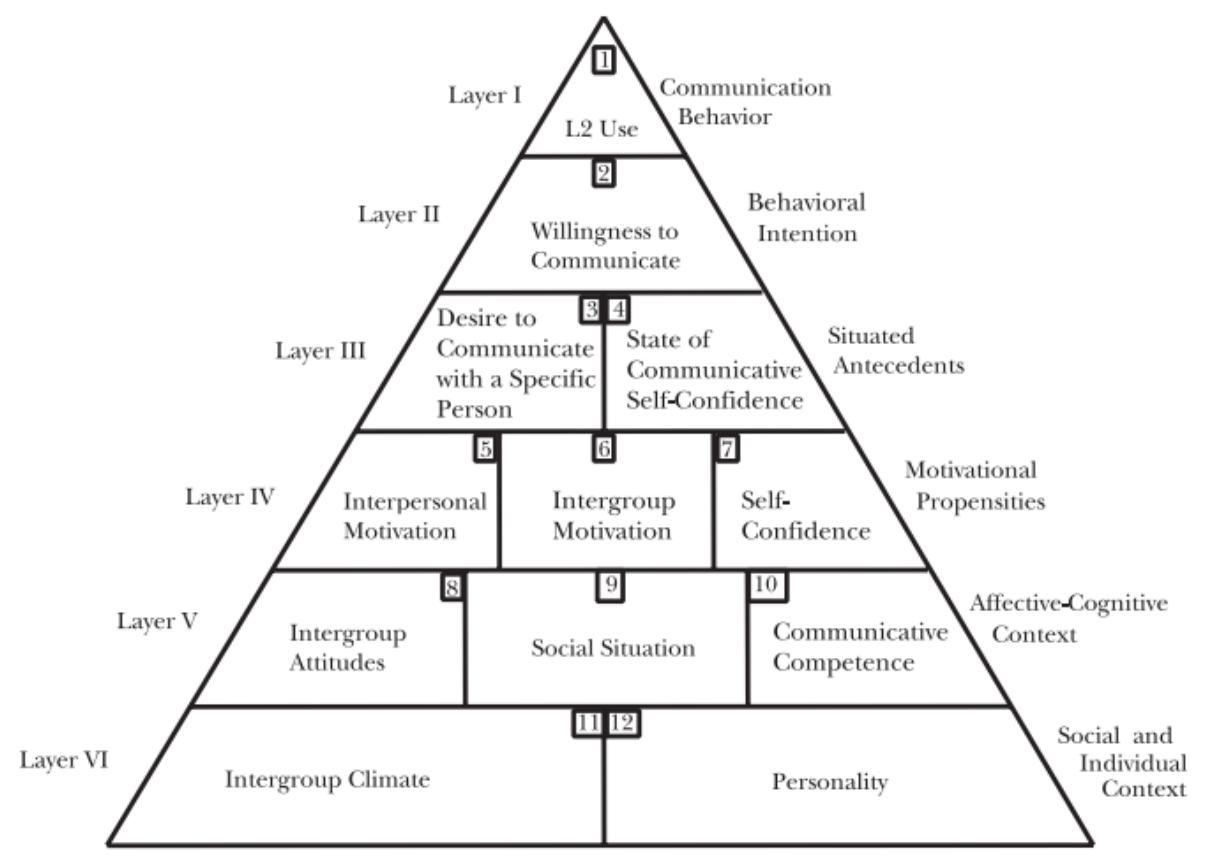

Figure 1. Pyramid Model of WTC

Willingness to communicate subsumes all the other variables represented in the triangle and is a readiness to speak in a second language. Those who have a higher WTC are predicted to use the second language more often. Willingness to communicate implies a greater likelihood of using a second language (MacIntyre et al., 1998).

Studies on WTC have shown that WTC is predictor of classroom participation in L1 (Chan \& McCroskey, 1987) and the initiation of communication in L1 (MacIntyre, Babin, \& Clément, 1999) and L2 (MacIntyre \& Carre, 2000). Therefore, willingness to communicate, which was suggested as the final intention to really initiate a communication, held a great value in the research of second and foreign language learning and instruction. (cf. McCroskey \& Baer, 1985). 
Tannenbaum and Tahar (2008) examined willingness to communicate among Jewish and Arab students of Israel. They found out that "the more favorable the participants' attitudes toward the TL, the higher their WTC in this language both inside and outside the classroom." (p. 287) They also showed that WTC outside the classroom is significantly lower than inside the classroom. Similarly, in Iran, Zarrinabadi and Abdi (2011) studied 67 intermediate university EFL students' WTC. Results show that language orientations are more correlated with willingness to communicate outside than inside the classroom.

In another study on Iranian students' WTC, Barjesteh, H., Vaseghi, R., and Neissi, S. (2012) indicated that learners are much more willing to communicate in group discussions and meetings with friends than other situations. They conclude that Iranian students are willing to initiate communication in situations experienced before, like group discussion or communicating with their friends.

Research in WTC is not limited only to EFL students. As such, Ghonsooly et al. (2012), investigated WTC among Iranian non-English major university students. His research participants were chosen among students of humanities (Arabic language and literature, social sciences, and geography) and Engineering students (computer, electronic, mechanic, industrial, and chemistry engineering). The results showed that L2 self-confidence and attitudes toward international community were two predictors of L2WTC in Iranian context. He has also suggested to investigate WTC among Iranian EFL students.

\subsection{Attitude toward the International Community-International Posture}

Learning a language is closely related to the attitudes towards the languages (Starks \& Paltridge, 1996). Karahan (2007, p.84) states that "positive language attitudes let learners have positive orientation towards learning English". Consequently, the important role of attitude in language learning would influence the success or failure of students in their learning.

Attitude is of two kinds: positive and negative. A person with positive attitude toward a behavior has a strong positive belief in that behavior to the extent that positive consequences will arise. However, those with negative attitude toward a behavior have wrong beliefs about that behavior from which negatively valued consequences will result. According to Krashen $(2007$, p. 84) those with positive attitude have positive orientation toward learning English. Consequently attitude can play an important role in success or failure of students. As mentioned by McIntyre (1998) social situation is a factor affecting students WTC. A research has been done on Iranian non-EFL students by Ghonsooly et al. (2012) but no study has been done on EFL students. Accordingly this study will be done on Iranian EFL students.

In classifying attitude, Gardner (1985) considers it as a component of motivation in language learning. He states, "motivation refers to the combination of effort plus desire to achieve the goal of learning the language plus favorable attitudes toward learning the language" (p. 10). However, Wenden (1991) proposed a broader definition of the concept "attitudes". He states that the term attitudes includes three components namely, cognitive, affective and behavioral. A cognitive component is made up of the beliefs and ideas or opinions about the object of the attitude. The affective one refers to the feeling and emotions that one has towards an object, 'likes' or 'dislikes', 'with' or 'against'. Finally, the behavioral component refers to one's consisting actions or behavioral intentions towards the object (ibid).

International posture is defined as a desire to learn English to communicate with the world. It is a general attitude towards the international community that "influences motivation [in learning a second language], which, in turn, predicts proficiency and second language communication confidence" (Yashima, 2002, p. 63). In community which English is not spoken as a daily language, learners do not have a clear affective reaction to a specific L2 group. They might learn English to be able to communicate with those who are living abroad, for example United States or other English speaking countries.

Therefore, several studies have been conducted to examine the relationship between international posture and L2WTC. International posture is shown to be one of the significant direct predictors of L2WTC (Matsuoka, 2005; Yashima, 2002; Yashima, Zenuk-Nishide, \& Shimizu, 2004). On the other hand, international posture can be considered an important affective cultural construct (Piggin, 2010). Accordingly, the results can be different in Iranian culture.

\section{The Proposed Model}

Based on previous studies the following hypothesized model is to be tested in this study. According to Yashima (2002) a path from International posture to L2 WTC is hypothesized. Proposed by McIntyre (1994) a path can be drawn from communicative competence to L2WTC. According to Yashima (2004) anxiety affects L2 communication confidence and confidence in turn affects L2 WTC. Another path is hypothesized from perceived 
communicative competence to L2 communication confidence (Ghonsooly, 2012).

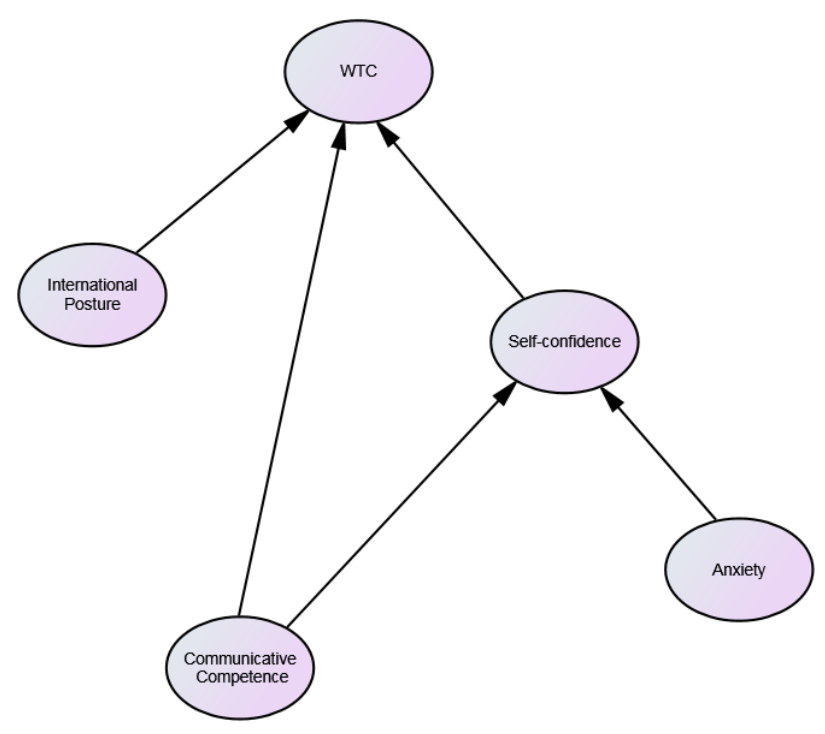

Figure 2. Hypothesized model

\section{Method}

\subsection{Subjects}

A sample of 194 learners participated in the current study. They were high-intermediate (140 learners) and advanced level (54) EFL (English as a Foreign Language) students of four prominent private language institutes in Sanandaj, a city in west of Iran. They included 113 females and 81 males whose age varied from 16 to 28. They were studying English language from 3 to 15 years.

\subsection{Instruments}

Questionnaires will be distributed among them to collect data needed for the study. Four questionnaires are employed in this study. Communication Anxiety Inventory, Communicative Competence Scale, Willingness to communicate scale, and international posture scale will be used to collect data for the study.

Willingness to Communicate: Twelve items (Cronbach's alpha = .94) from McCroskey (1992) were used to assess participants willingness to communicate in English in terms of the communication context (public speaking, talking in meetings, group discussions, and interpersonal conversations) and types of receivers (stranger, acquaintance, and friend). The respondents chose the percentage of the time ranging from $0 \%$ to $100 \%$ that they would be willing to communicate in each case.

Perceived Communication Competence: Twelve items (Cronbach's alpha $=.95$ ) used by Yashima (2002) and MacIntyre and Charos (1996) were utilized to assess the extent to which the respondents feel confident communicating in English. The respondents self-evaluated their English competence by selecting a number ranging from $0 \%$ (entirely incompetent) to $100 \%$ (entirely competent). In this scale, the context and receivers of communication were the same with the WTC scale.

Communication Anxiety: This was measured by twelve items (Cronbach's alpha = .93) used by Yashima $(2002)$. The respondents self-assessed their communication anxiety in English by indicating a percentage between $0 \%$ (do not feel anxiety at all) and 100\% (always feel anxiety). The items covered the same context of communication and receivers as WTC and Perceived Communication Competence scales.

International posture inventory included following three sub categories:

Approach-Avoidance Tendency: Seven items (Cronbach's alpha $=.77$ ) adapted from Yashima (2002) were used to measure the respondents' tendency to approach or avoid English-speaking foreigners. Again, students indicated their degree of agreement on a 5-point scale by choosing a number between 1 (strongly disagree) and 5 (strongly agree). 
Interest in International Vocation/Activities: Six items (Cronbach's alpha $=.62)$ adopted from Yashima (2002) were used to measure the degree of interest that a respondent showed in having an international career or living abroad. The respondents recorded their ratings on a 5-point scale by choosing a number between 1 (strongly disagree) and 5 (strongly agree). An example item is "I want to live in a foreign country."

Interest in Foreign Affairs: Two items (Cronbach's alpha $=.80$ ) adopted from Yashima (2002) were used to measure the respondents' interest in international matters. An example item is "I often read and watch news about foreign countries." Again, students indicated their degree of agreement on a 5-point scale by choosing a number between 1 (strongly disagree) and 5 (strongly agree).

Self-Confidence: this scale is a standardized scale currently used by psychologists of Office of Education in counselling centers of Sanandaj. It consists of 25 items to assess the self-confidence level of subjects. The reliability index (Cronbach's alpha) for this questionnaire is .92 .

All the questionnaires, except for self-confidence scale which was originally in Persian, were translated into Persian. The items of each inventory were first translated into Persian and then were back translated to ensure the conceptual equivalence of the translated versions of the scales with their main version. Slight modifications were made in the items of the scales to make them more proper to use in the Iranian EFL context. The Cronbach's alpha for the Persian translation of questionnaire is shown in Table 1.

Table 1. Reliability of Persian version of scales

\begin{tabular}{cccccc}
\hline & Anxiety & $\begin{array}{c}\text { International } \\
\text { Posture }\end{array}$ & $\begin{array}{c}\text { Communicative } \\
\text { Competence }\end{array}$ & $\begin{array}{c}\text { Willingness to } \\
\text { Communicate }\end{array}$ & $\begin{array}{c}\text { Self } \\
\text { Confidence }\end{array}$ \\
\hline $\begin{array}{c}\text { Cronbach's } \\
\text { Alpha }\end{array}$ & .914 & .865 & .883 & .900 & .92 \\
\hline
\end{tabular}

\subsection{Procedure and Data Analysis}

The administrators and principals of the four private language institutes were contacted to obtain permission for conducting the research project. They were first asked about the nature of the classes to ensure that learners enrolling in the four language institutes follow general communicative purposes. The participants were then asked to complete the questionnaires. The data collection began in January 2015 and ended in February 2015.

The gathered data were first converted into a computer file via SPSS version 22. Then the data were screened and cleaned to gain a fully-crossed dataset (a prerequisite for structural equation modeling analysis). The first analysis step was checking correlations among the variables using Pearson correlation coefficient. The second step involved the examination of the structural model comprising of the variables of the study which was carried out via AMOS version 22. Before running the structural model, measurement models were examined to check the validity of the linkage between the latent and observed variables. Eight intra-scale correlational paths were drawn between the items in order to satisfy the basic validity requirements of the model.

After running the structural model, certain fitness criteria were consulted to investigate the goodness of fit of our model to the data. The first consulted evaluative criterion was chi-square value. Despite being commonly reported in SEM studies, the statistical use of this value is believed to be in question as it is largely affected by the sample size. Apart from chi-square, chi-square to degree of freedom ratio $\left(\mathrm{x}^{2} / \mathrm{df}\right)$ and other overall model fit criteria were also consulted. For $x_{x}^{2} / d f$ a value smaller than 3 is assumed to be statistically acceptable (Skaalvik \& Skaalvik, 2009). The overall consulted model fit indices included goodness of fit index (GFI), root mean square of approximation (RMSEA), comparative fit index (CFI), incremental fit index (IFI), Tuker-lewis index (TLI), and normal fit index (NFI). For all these indices except RMSEA, values larger than 0.90 on a scale of zero to one, are considered to be good. As for RMSEA, a value below .05 is considered to be a good index of model fit (Bentler, 2007).

\section{Results}

\subsection{Correlational Analysis}

Table 2 reports the correlations among the main variables of the study. As demonstrated, L2 communication anxiety is negatively correlated with other four variables. The correlation for WTC and self-confidence, WTC and international posture, and WTC and communicative competence were .446, .447, and .501 respectively. They were all significant at $\mathrm{p}<.01$. Correlations between anxiety and WTC was -.502 . Anxiety was also 
negatively correlated with international posture (-.323), self-confidence (-.493), and communicative competence (-.328). Table 1 also demonstrates the correlation between international posture and self-confidence (.290), international posture and communicative competence (.337), and self-confidence and communicative competence (.372). All the correlations were significant at $\mathrm{p}<.01$.

Table 2. Correlations among measured variables.

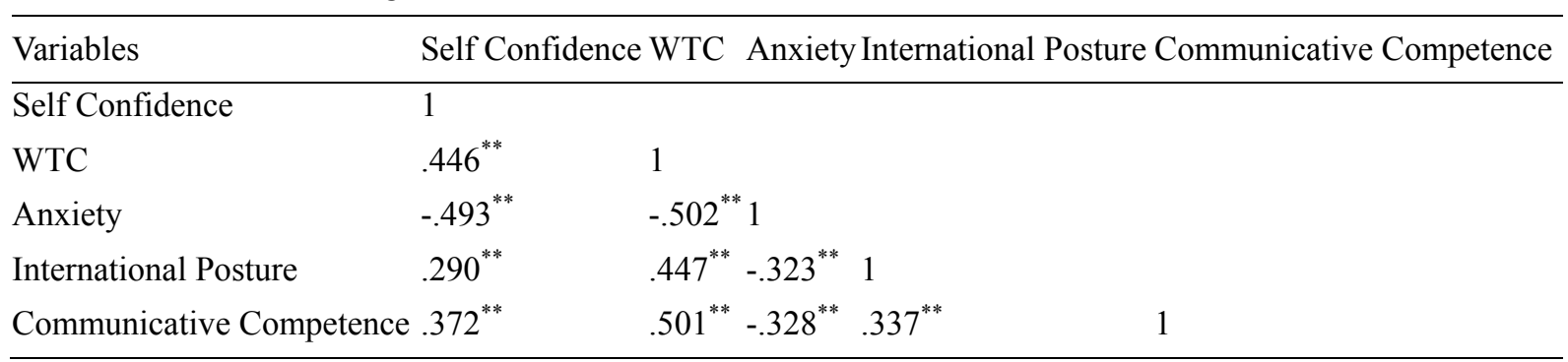

** Correlation is significant at the 0.01 level.

\subsection{Structural Model Analysis}

Figure 3 demonstrates the final structural model of the study with standardized path coefficients. As can be seen in Table 3, the chi-square is significant, indicating insufficient model fit. But as noted earlier, chi-square is highly affected by the sample size. To solve this problem, chi-square to degrees of freedom ratio $\left(\mathrm{x}^{2} / \mathrm{df}\right)$ is consulted, which in case of our study displays a value (2.27) below the acceptable level of 3; furthermore, all the selected model fit indices show very good levels. Thus, it can be concluded that the final version of this model is an acceptable representation of our dataset concerning the measured variables. As indicated, all the hypothesized paths came out to be significant in different levels which is in accord with the literature (McIntyre, 1994; Yashima, 2002; Yashima, 2004; Ghonsooly, 2012). These paths were international posture $\rightarrow$ L2WTC, L2 self-confidence $\rightarrow$ L2 WTC, anxiety $\rightarrow$ L2 self-confidence, communicative competence $\rightarrow$ L2WTC, communicative competence $\rightarrow$ L2 self-confidence. All these paths were significant at $\mathrm{p}<.001$ level.

Two new correlational paths were found to be significant in this study. The first and more powerful one was a two-headed path between communicative competence and international posture. It can be concluded that international posture motivates students to improve their language knowledge and on the other hand those who are more powerful in language have more tendencies to go abroad. Another correlational path which came out to be significant in this study was the correlation between communicative competence and anxiety. As far as the factor loading value is negative, we can say that anxious students are less competent in English language and vice versa. Although it is already discussed by Hoshimoto (2002) that anxiety affects perceived communicative competence, here in this study it we found that perceived communicative competence affects anxiety in the same way that anxiety affects perceived communicative competence. Consequently, the path between these two variables is a two headed correlational path. These two paths were significant at $\mathrm{p}<.01$ level. 


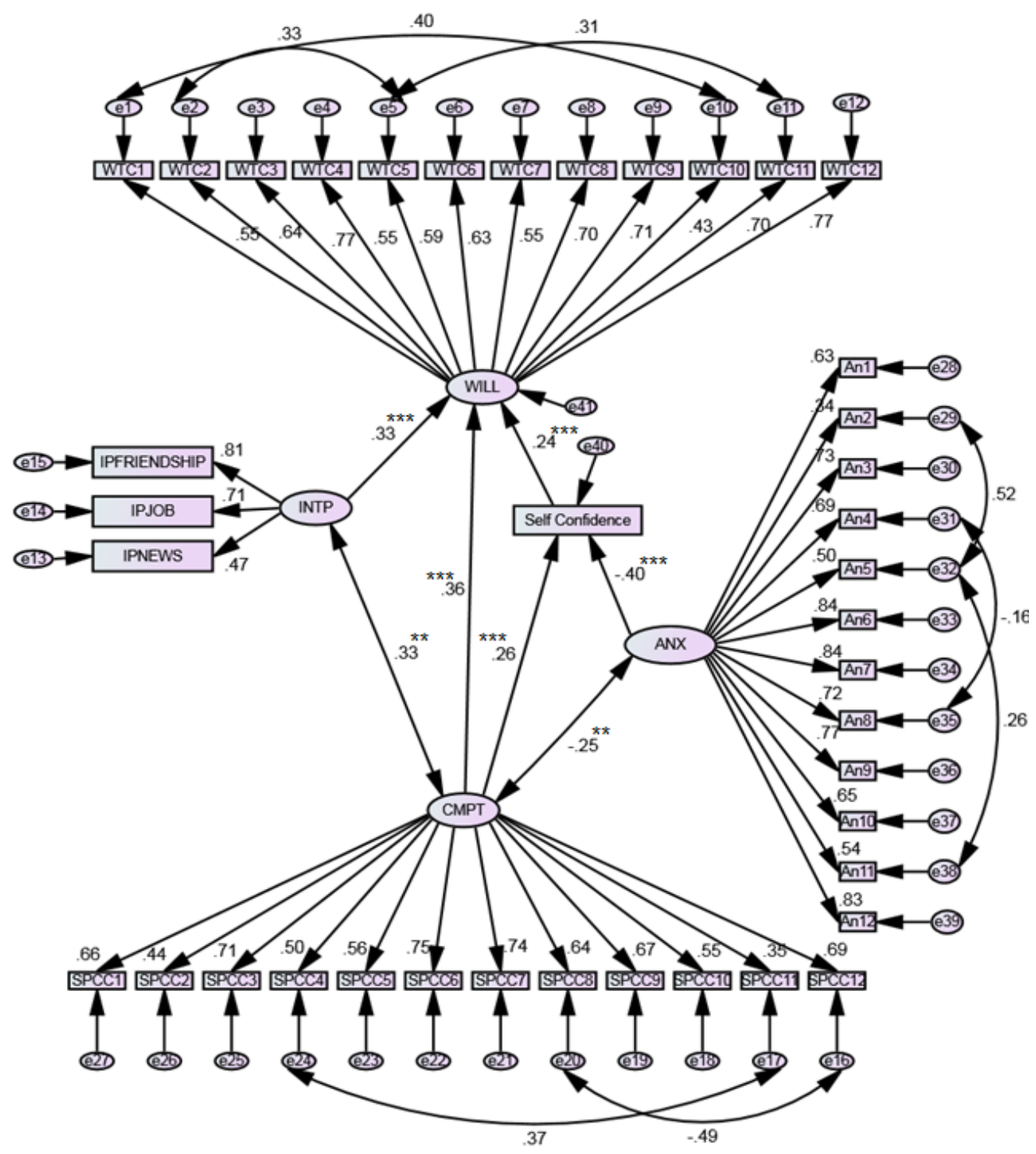

Figure 3. The final model of willingness to communicate

Note: WILL: Willingness to Communicate; INTP: International Posture; CMPT: Communicative Competence; ANX: Anxiety.

Flagged path coefficient indicates the level of significance. ${ }^{* *} \mathrm{p}<.01,{ }^{* * *} \mathrm{p}<.001$.

As it is shown in Table 3, all other indices, except for chi-square value, came out to be in an acceptable level suggesting a good model fit for our data. Overall, it can be said that the final structural model of the present study gives us a proper picture of the data and the measured variables of the study. 
Table 3. Fitness measures for the final model

\begin{tabular}{llll}
\hline Index & Obtained level & Accepted level & Evaluation \\
\hline $\mathbf{X}^{\mathbf{2}}$ & $\mathrm{p}<.05$ & $\mathrm{P}>.05$ & Poor \\
\hline $\mathbf{X}^{\mathbf{2}} / \mathbf{d f}$ & 2.27 & $<3$ & Very good \\
\hline GFI & .94 & $>.90$ & Very good \\
\hline $\mathbf{N F I}$ & .93 & $>.90$ & Very good \\
\hline $\mathbf{R F I}$ & .92 & $>.90$ & Very good \\
\hline IFI & .95 & $>.90$ & Very good \\
\hline TLI & .94 & $>.90$ & Very good \\
\hline CFI & .96 & $>.90$ & Very good \\
\hline RMSEA & .039 & $<.05$ & Good \\
\hline
\end{tabular}

Note: GFI: Goodness of Fit Index; NFI: Normal Fit Index; IFI: Incremental Fit Index; RFI: Relative Fit Index; TLI: Tucker-Lewis Index; CFI: Comparative Fit Index; RMSEA: Root Mean Square Error of Approximation.

\section{Discussion}

The results of the study provide several points to be discussed. First, the strongest predictor of WTC which is not in accord with the literature. The previous studies (Yashima, 2002; Clément, Baker, and MacIntyre, 2003; Ghonsooly, 2012) have founded L2 self-confidence as the stronger predictor of WTC but we L2 communicative competence is the strongest predictor of WTC. This seemingly inconsistent obtained finding is explicable in the light of the nature of our sample. The EFL learners in this study learned English in private language institutes. They were mostly teenagers who had a false self-confidence. Since the subjects of Ghonsooly (2012) was university non-EFL students and ours was private language institutes' students, it can be discussed that as far as university non-EFL students have to pass English courses as an obligatory course suggested by their university, are less confident in their abilities. As a resolution, students who have higher communicative competence are more willing to communicate in English than those who perceive their communicative competence as low.

Another significant path was that of international posture to WTC. As predicted, attitude toward intercultural communication or international interest directly influenced WTC in the L2. This finding is in line with the finding of Yashima (2002). It is not surprising that the more internationally oriented an individual was, the more willing he or she was to communicate in English. Such individuals are also more motivated to study English, and this leads them to improve their communicative competence. Consequently, a new correlational path between international posture and communicative competence appeared to be significant. Based on this path, it can be inferred that those who see themselves as competent language speakers, are more willing to integrate in international communication.

Another finding worthy of attention in the final model is the impact of communicative competence on L2 self-confidence. As it can be seen in the model, communicative competence affects WTC both directly and indirectly through L2 self-confidence. Based on the reviewed literature, communicative competence is one of the major predictors of L2 self-confidence (Yashima, 2012). Consequently, competent students felt a higher confidence in their abilities and this led to a higher willing to communicate in English. This finding supports the findings of Hashimoto (2002), Yashima (2012), Ghonsooly (2012).

The other path to be discussed is the correlational path between communicative competence and anxiety. It has been verified by Hashimoto (2002), Macintyre (1994), and Macintyre and Charos (1996) anxiety has a negative effect on communicative competence. As a new finding, we found out that communicative competence also has a negative effect an anxiety. As a result, those who feel more competent in English language, are less anxious and consequently more confident. On the other hand, as far as the factor loading of this path is significant at $\mathrm{p}<0.01$ level, the validity and generalizability of this path need to be further investigated in future studies.

The negative effect of anxiety on L2 self-confidence has been confirmed by our model. This finding is in line with the previous studies (Macintyre, 1994; and Macintyre and Charos, 1996; Hashimoto, 2002; Yashima, 2002; Ghonsooly, 2012). Regarding the literature, a path from self-confidence to willingness to communicate appeared to be significant. So the more confident students are more willing to communicate in English. So it can be concluded that anxious students are less confident and consequently less willing to start or maintain 
communication.

The last but not least important path to be discussed is the correlational path between international posture and communicative competence. As noted earlier, there is no literature for this path and it is data-driven. The logic to justify this path can be related to the motivation of students. International posture as an attitude to integrate in international affairs motivates students to work on their English language capabilities and consequently become more competent in English. On the other hand, more competent students will become more interested in international communities. Since adding additional paths is regarded as exploratory, and data-driven, this path needs to be replicated and should be further investigated.

\section{Conclusion}

This study examined the relationship among different variables affecting WTC, including anxiety, L2 self-confidence, L2 communicative competence, and international posture. Unlike other studies in Iran which had targeted high school and university students, the sample of this study comprised of Iranian EFL learners learning English at private language institutes so the discrepancy between our findings and literature is not much surprising. Communicative competence was found to be the strongest predictor of L2WTC. The direct and indirect effect of communicative competence on WTC shows that by increasing communicative competence other predictors of WTC would change in a way to increase students' WTC.

Nonetheless, this study has some implications for teachers. One is that by increasing perceived competence and reducing language anxiety, the willingness to communicate may lead to more language use in the classroom. Creating a less threatening atmosphere to reduce anxiety and encouraging students to increase perceived competence may be effective in increasing willingness to communicate and frequency of L2 use in classrooms with Iranian ESL students.

\section{References}

Bachman, L. (1990). Fundamental considerations in language testing. Oxford: Oxford University Press.

Barjesteh, H., Vaseghi, R., \& Neissi, S. (2012). Iranian EFL learners' willingness to communicate across different context-and receiver-types. International Journal of English Linguistics, 2(1), 47-54. http://dx.doi.org/10.5539/ijel.v2n1p47

Barraclough, R. A., Christophel, D. M., \& McCroskey. J. C. (1988). Willingness to communicate: A crosscultural $\begin{array}{llll}\text { investigation. } & \text { Communication Reports, } & \text { 187-192. }\end{array}$ http://dx.doi.org/10.1080/08824098809359822

Bentler, P. M. (2007). On tests and indices for evaluating structural models. Personality and individual differences, 42, 825-829. http://dx.doi.org/10.1016/j.paid.2006.09.024

Burroughs, N. F., \& Marie, V. (1990). Communication orientations of Micronesians and American students. Communication Research Reports, 7, 139-146. http://dx.doi.org/10.1080/08824099009359868

Burroughs, N. F., Marie, V., \& McCroskey, J. C. (2003). Relationships of self-perceived communication competence and communication apprehension, to willingness to communicate: A comparison of first and second languages in Micronesia. Communication Research Report, 20(3), 230-239. http://dx.doi.org/10.1080/08824090309388821

Canale, M., \& Swain, M. (1980). Theoretical bases of communicative approaches to second language teaching and testing. Applied Linguistics, 1, 1-47. http://dx.doi.org/10.1093/applin/I.1.1

Chan, B., \& McCroskey, j. C. (1987). The WTC scale as a predictor of classroom participation. Communication Research Reports, 4, 47-50.

Charos, C. (1994). Personality and individual differences as predictors of second language communication: A causal analysis. Unpublished Honors Thesis, University of Ottawa, Canada.

Cheng, Y., Horwitz, E. K., \& Schallert, D. L. (1999). Language anxiety: Differentiating writing and speaking components. Language Learning, 49, 417-446. http://dx.doi.org/10.1111/0023-8333.00095

Clément, R., Baker, S. C., \& MacIntyre, P. D. (2003). Willingness to communicate in a second language: The effect of context, norms and vitality. Journal of Language and Social Psychology, 22(2), 190-209. http://dx.doi.org/10.1177/0261927X03022002003

Clément, R, Gardner, R. C., \& Smythe, P. C. (1980). Social and individual factors in second language acquisition. Canadian Journal of Behavioral Science, 12, 293302. http://dx.doi.org/10.1037/h0081081 
Clément, R. (1980). Ethnicity, contact, and communicative competence in a second language. In H. Giles, W. P. Robinson, \& P. M. Smith (Eds.), Language: Social psychological perspectives (pp. 147-154). New York, NY: Pergamon.

Clément, R. (1986). Second language proficiency and acculturation: An investigation of the effects of language status and individual characteristics. Journal of Language and Social Psychology, 5, 71-90. http://dx.doi.org/10.1177/0261927x8600500403

Clément, R., Dörnyei, Z., \& Noels, K. A. (1994). Motivation, self-confidence, and group cohesion in the foreign language classroom. Language Learning, $417-448$. http://dx.doi.org/10.1111/j.1467-1770.1994.tb01113.x

Dörnyei, Z. (2003). Attitudes, orientations, and motivations in language learning: Advances in theory, research, and applications. Language Learning, 53(1), 3-32. http://dx.doi.org/10.1111/1467-9922.53222

Gardner, R. C. (1985). Social psychology and second language learning: The role of attitudes and motivation. London: Arnold.

Gardner, R. C., \& MacIntyre, P. D. (1993). A student's contribution to second language learning: Part II, affective factors. Language Teaching, 26, 1-11. http://dx.doi.org/10.1017/S0261444800000045

Ghonsooly, B., Khajavy, G.H., \& Asadpour, S. F. (2012). Willingness to communicate in English among Iranian non-English major university students. Journal of Language and Social Psychology, 31, $197-211$. http://dx.doi.org/10.1177/0261927X12438538

Hashimoto, Y. (2002). Motivation and willingness to communicate as predictors of reported L2 use: The Japanese ESL context. Second Language Studies, 20, 29-70.

Heyde, A. (1979). The relationship between self-esteem and the oral production of a second language. Unpublished doctoral dissertation, University of Michigan, MI.

Horwitz, E. (1986). Preliminary evidence for the reliability and validity of a foreign language anxiety scale. TESOL Quarterly, 20, 559-564. http://dx.doi.org/10.2307/3586302

Horwitz, E. K., Horwitz, M. B., \& Cope, J. (1986). Foreign language classroom anxiety. Modern Language Journal, 70, 125-132. http://dx.doi.org/10.1111/j.1540-4781.1986.tb05256.x

Hsu, L. L. (2005). The relationship among teachers' verbal and nonverbal immediacy behaviors and students' willingness to speak in English in central Taiwanese college classrooms. Unpublished doctoral dissertation, Oral Roberts University, Tulsa, Oklahoma.

Karahan, F. (2007). Language attitudes of Turkish students towards the English language and its use in Turkish context. Journal of Arts and Sciences Say, 7 May, 73-87.

Karahan, F. (2007). Language attitudes of Turkish students towards the English language and its use in Turkish context. Journal of Arts and Sciences, 7, 73-87.

Kim, S. J. (2004). Exploring willingness to communicate (WTC) in English among Korean EFL (English as a foreign language) students in Korea: WTC as a predictor of success in second language acquisition. Unpublished doctoral dissertation, Ohio State University, Columbus, Ohio.

MacIntyre, P. D., \& Carre, G. (2000, July). Personality and willingness to communicate in a second language: A critique of the communibiological approach. Paper presented at the seventh International Congress on Language and Social Psychology, Cardiff, Wales.

Macintyre, P. D., \& Charos, C. (1996). Personality, attitudes, and affect as predictors of second language communication. Journal of Language and Social Psychology, 15, 3-26. http://dx.doi.org/10.1177/0261927X960151001

MacIntyre, P. D., \& Clément, R. (1996, August). A model of willingness to communicate in a second language: The concept, its antecedents and implications. Paper presented at the World Congress of Applied Linguistics (AILA), Jyväskylä, Finland.

MacIntyre, P. D., \& Gardner, R. C. (1991). Methods and results in the study of anxiety and language learning: A review of the literature. Language Learning, 41, 85-115. http://dx.doi.org/10.1111/j.1467-1770.1991.tb00677.x

MacIntyre, P. D., Babin, P. A., \& Clément, R. (1999). Willingness to communicate: Antecedents and consequences. Communication Quarterly, 47, 215-229. http://dx.doi.org/10.1080/01463379909370135 
MacIntyre, P. D., Clément, R., Dörnyei, Z., \& Noels, K. A. (1998). Conceptualizing willingness to communicate in a L2: a situational model of L2 confidence and affiliation. Modern Language Journal, 82, 545e562. http://dx.doi.org/10.1111/j.1540-4781.1998.tb05543.x

MacIntyre, P. D., Noels, K. A., \& Clément, R. (1997). Biases in self-ratings of second language proficiency: The role of language anxiety. Language Learning, 47, 265287. http://dx.doi.org/10.1111/0023-8333.81997008

MacIntyre, P.D., Baker, S.C., Clément, R., \& Conrod, S. (2001).Willingness to communicate, social support, and language-learning orientations of immersion students. Studies in Second Language Acquisition, 23, 369-388. http://dx.doi.org/10.1017/S0272263101003035

Matsuoka, R. (2005). Japanese students' willingness to communicate in English (Unpublished doctoral dissertation). Temple University, Pennsylvania, PA.

McCroskey, J. C, \& Richmond, V. P. (March, 1985). Willingness to communicate and interpersonal communication. Paper presented at the West Virginia Symposium on Personality and Interpersonal Communication, Morgantown, WV.

McCroskey, J. C, \& Richmond, V. P. (1987).Willingness to Communicate. In J. C. McCroskey, \& J. A Daly (Eds.), Personality and interpersonal communication (pp. 129-156). Newbury Park, CA: Sage.

McCroskey, J. C., \& McCroskey, L. L. (1988). Self-report as an approach to measuring communication competence. Communication Research Reports, 5, 108-113. http://dx.doi.org/10.1080/08824098809359810

McCroskey, J. C., \& Richmond, V. P. (1990). Willingness to communicate: A cognitive view. In M. Booth-Butterfield (Ed.), Communication, cognition, and anxiety (pp. 19-37). Newbury Park, CA: Sage.

McCroskey, J. C., Burroughs, F., Daun, A., \& Richmond, V. P. (1990). Correlates of quietness: Swedish and $\begin{array}{llll}\text { American } & \text { perspectives. }\end{array}$ http://dx.doi.org/10.1080/01463379009369749

McCroskey, J. C., \& Baer, J. E. (November, 1985). Willingnessto communicate: The construct and its measurement. Paper presented at the Speech Communication Association convention, Denver, CO.

Noels, K. A., Pon, G., \& Clément, R. (1996). Language, identity, and adjustment: The role of linguistic self-confidence in the acculturation process. Journal of Language and Social Psychology, 15, 246-264. http://dx.doi.org/10.1177/0261927X960153003

Oxford, R. L. \& Shearin, J. (1994). Language learning motivation: Expanding the theoretical framework. Modern Language Journal, 78(1), 12-28. http://dx.doi.org/10.1111/j.1540-4781.1994.tb02011.x

Piggin, G. (2010). A Case Study of How International Posture Affects Japanese EFL Learners' L2 Willingness to Communicate. 文教大学国際学部紀要, 21(1), 1-14.

Rachman. (1998). Anxiety, Psychology Press. Hove. East Sussex, UK.

Sallinen-Kuparinen, A., McCroskey, J. C., \& Richmond, V. (1991). Willingness to communicate, communication apprehension, introversion, and self-reported communication competence: Finnish and American comparisons. Communication Research Reports, 8, 55-64. http://dx.doi.org/10.1080/08824099109359876

Skaalvik, E. M., \& Skaalvik, S. (2009). Does school context matter? Relations with teacher burnout and job satisfaction. Teaching and Teacher Education, 25(3), 518-524. http://dx.doi.org/10.1016/j.tate.2008.12.006

Spielberger, C. D. (1983). Manual for the State-Trait Anxiety Inventory STAI (form Y) ("Self-Evaluation Questionnaire”). California: Consulting Psychology Press.

Starks, D., \& Paltridge, B. (1996). A note on using sociolinguistic methods to study nonnative attitudes towards English. World Englishes, 15(2), 217-224. http://dx.doi.org/10.1111/j.1467-971X.1996.tb00107.x

Tannenbaum, M., \& Tahar, L. (2008). Willingness to communicate in the language of the other: Jewish and Arab students in Israel. Learning and Instruction, 18(3), 283-294. http://dx.doi.org/10.1016/j.learninstruc.2007.06.002

Wen, W. P., \& Clément, R. (2003). A Chinese conceptualization of willingness to communicate in ESL. Language, Culture and Curriculum, 16(1), 18-38. http://dx.doi.org/10.1080/07908310308666654

Yashima, T. (2002). Willingness to communicate in a second language: The Japanese EFL context. Modern Language Journal, 86, 55-66. http://dx.doi.org/10.1111/1540-4781.00136

Yashima, T., Zenuk-Nishide, L., \& Shimizu, K. (2004). The influence of attitude and affect on willingness to 
communicate and second language communication. Language Learning, 54(1), 119-152. http://dx.doi.org/10.1111/j.1467-9922.2004.00250.x

Zarrinabadi, N., \& Abdi, R. (2011). Willingness to communicate and language learning orientations in Iranian EFL context. International Education Studies, 4(4), 206-214. http://dx.doi.org/10.5539/ies.v4n4p206

\section{Copyrights}

Copyright for this article is retained by the author(s), with first publication rights granted to the journal.

This is an open-access article distributed under the terms and conditions of the Creative Commons Attribution license (http://creativecommons.org/licenses/by/3.0/). 